\title{
A virus-induced gene silencing method to study soybean cyst nematode parasitism in Glycine max
}

\author{
Pramod K Kandoth', Robert Heinz ${ }^{1}$, Greg Yeckel ${ }^{1,3}$, Nathan W Gross ${ }^{1,4}$, Parijat S Juvale ${ }^{2}$, John Hill ${ }^{2}$, Steven A Whitham²,
} Thomas J Baum² and Melissa G Mitchum ${ }^{1 *}$

\begin{abstract}
Background: Bean pod mottle virus (BPMV) based virus-induced gene silencing (VIGS) vectors have been developed and used in soybean for the functional analysis of genes involved in disease resistance to foliar pathogens.

However, BPMV-VIGS protocols for studying genes involved in disease resistance or symbiotic associations with root microbes have not been developed.

Findings: Here we describe a BPMV-VIGS protocol suitable for reverse genetic studies in soybean roots. We use this method for analyzing soybean genes involved in resistance to soybean cyst nematode (SCN). A detailed SCN screening pipeline is described.

Conclusions: The VIGS method described here provides a new tool to identify genes involved in soybean-nematode interactions. This method could be adapted to study genes associated with any root pathogenic or symbiotic associations.
\end{abstract}

Keywords: Heterodera glycines, Resistance, SCN, Soybean, Cyst nematode, Resistance, Virus-induced gene silencing, VIGS

\section{Background}

Virus-induced gene silencing (VIGS) is a reverse genetic tool that exploits RNA-mediated antiviral defense strategies used by plants [1]. VIGS is based on the formation of double-stranded RNA intermediates and structured single-stranded RNAs, which are formed during virus infection [2]. DICER-like ribonucleases digest the dsRNAs to produce 21-22 nucleotide long small interfering RNAs (siRNAs). These siRNAs, as part of RNA Induced Silencing Complex (RISC), lead to sequence-specific degradation of viral RNAs [3]. When a portion of an endogenous gene is inserted in the viral genome and introduced into plants, siRNAs specific to the endogenous gene are produced and lead to targeted degradation of endogenous gene transcripts [1,4]. VIGS has several advantages over other reverse genetic tools. For one, VIGS produces rapid and transient phenotypes. In addition, the methodology is relatively inexpensive and does not require the development of plant transformation protocols. VIGS is also

\footnotetext{
* Correspondence: goellnerm@missouri.edu

${ }^{1}$ Division of Plant Sciences, Christopher S. Bond Life Sciences Center and Interdisciplinary Plant Group, University of Missouri, Columbia, MO 65211, USA

Full list of author information is available at the end of the article
}

particularly useful for functional studies of genes with lethal phenotypes upon silencing.

VIGS methodology coupled with biochemical and genetic analyses has been successfully used to functionally characterize plant genes involved in fruit ripening, cell wall composition and plant defense against pathogens and insects [5-12]. Consequently, VIGS has become a powerful reverse genetic tool for functional genomics of crop plants that are not amenable to genetic transformation. Several VIGS vectors have been developed [4,13]. Once developed, VIGS vectors are easy to use and the assays require minimal labor, making the technology ideally suited for high throughput screening of a large number of genes. Currently, soybean transformation procedures are time consuming and cumbersome. A DNA-based VIGS vector was recently developed using Bean pod mottle virus (BPMV) [14,15]. This vector was successfully used for the study of soybean genes involved in resistance to Asian soybean rust $[16,17]$. Recently available soybean genome sequence information [18] and the increasing importance of soybean as a food crop, has led to a tremendous interest in identifying the genes essential for defense against various pathogens, abiotic stress tolerance, and nutritional quality. 
Here our aim was to develop an SCN-BPMV-VIGS protocol to extend the use of VIGS for functional analysis of soybean genes involved in resistance to SCN, which is the number one pathogen of soybean in the United States. SCN feeds on the roots of soybean and causes annual yield losses worth more than one billion dollars in the United States alone. To date, VIGS protocols developed for use in soybean have focused on silencing of genes in foliar tissues. Therefore, it is desirable to have a methodology to study loss of function of genes in roots. Here, we describe a VIGS method suitable for gene silencing in soybean roots and demonstrate the methodology by successful silencing of a gene involved in SCN resistance.

\section{Methods}

\section{Construction of VIGS plasmids}

BPMV is a positive strand RNA virus belonging to the Comoviridae family. The virus has a bipartite genome. BPMV vectors were previously made by cloning RNA1 (essential for viral replication and maintenance; pBPMVIA-R1M) and RNA2 (pBPMV-IA-R2) in plasmid vectors [14] (Note 1). The BPMV-R2 vector used in this study, pBPMV-IA-D35, was modified from the vector described in [14] by engineering $B a m H 1$ and $K p n I$ cloning sites between the cistrons encoding the viral movement protein and the large coat protein subunit. Inserts are cloned in frame with the viral genes. An extra ' $\mathrm{T}$ ' is introduced in the reverse primer to maintain the reading frame. We used a 328 bp fragment corresponding to the 5 ' region of a soybean serine hydroxymethyltransferase (SHMT) gene (bps 210-537; GmSHMT cDNA sequence, Genbank Accession No. JQ714080) to generate an SHMT-VIGS (pBPMV-SHMT) construct. The BPMV vector without an insert (pBPMV vector only) was used as a control.

\section{VIGS tissue preparation}

The VIGS inoculum used in this protocol is generated from infected leaf tissues. Seven-day-old soybean seedlings are used for biolistic delivery of virus vector DNA into leaf tissues. For this, seeds are germinated in Sunshine MVP mix (SunGro Horticulture, Bellevue, WA) in 36 -well insert trays at $26^{\circ} \mathrm{C}$. Soybean seeds of two recombinant inbred lines, EXF67 and EXF63, derived from a cross between the soybean cultivars Essex and Forrest, were used (Note 2). EXF67 and EXF63 are resistant and susceptible, respectively, to the soybean cyst nematode inbred population PA3 (Hg Type 0 ). On the day of bombardment, the wells are separated and each well (pot) containing a single healthy seedling with unifoliate leaves is used for biolistic transformation. To generate infected tissues, plasmid DNA encoding RNA1 is co-bombarded into soybean leaves with either RNA2 pBPMV-SHMT or pBPMV vector only using a BioRad $^{\circledR}$ PDS-1000/He biolistic transformation system (BioRad, USA) using the following procedure:

- Prepare DNA by plasmid prep.

- Coat $1 \mu \mathrm{m}$ gold particles (BioRad cat. No. 165-2263) with $5 \mu \mathrm{g}$ of DNA (R1:R2; $2 \mu \mathrm{g}: 3 \mu \mathrm{g}$ ) as described in the following steps:

1. Sonicate $50 \mu \mathrm{l}$ gold particles (Note 3) briefly for 15-30 sec. Add $5 \mu \mathrm{g}$ DNA (volume $\leq$ to $5 \mu \mathrm{l}$ ) to $50 \mu \mathrm{l}$ gold particles.

2. Vortex at low speed. While vortexing, add $25 \mu \mathrm{l} 2 \mathrm{M}$ $\mathrm{CaCl}_{2}$ and $10 \mu \mathrm{l} 0.1 \mathrm{M}$ spermidine.

Vortex for $10 \mathrm{~min}$.

3. Allow to sit for $30 \mathrm{sec}$.

4. Centrifuge at $1400 \mathrm{rpm}$ in a microfuge and discard the supernatant.

5. Add $140 \mu \mathrm{l} 100 \%$ ethanol and re-suspend the gold particles by vigorous tapping. Centrifuge again to remove supernatant.

6. Repeat the ethanol wash two more times.

7. Finally re-suspend the DNA-coated gold particles in $28 \mu \mathrm{l}$ of $100 \%$ ethanol.

8. Vortex and mix the gold particles. While vortexing, pipette $10 \mu \mathrm{l}$ volume and spread on the middle of three macrocarriers (BioRad cat. No. 165-2335). Allow the ethanol to evaporate.

9. Assemble the gene gun with 1100 psi rupture disk (BioRad cat. No.165-2329), macrocarrier with coated gold particles and stop screen (BioRad cat. No. 165-2336).

- Place one soybean seedling at a time in the gene gun chamber with unifoliate leaves supported by a plexiglass plate and a wire mesh placed on top to hold the leaves in place. Apply vacuum.

- Bombard the leaves when vacuum reaches 28-inch $\mathrm{Hg}$. Take out the plant, immediately spray with a mist of water. Keep the plants in a tray with a plastic dome cover to maintain humidity. Later, move the tray to $20^{\circ} \mathrm{C}$ and maintain overnight.

- The plants are then transplanted to $10 \mathrm{~cm}$ diameter plastic pots with Sunshine MVP mix and kept at $20^{\circ} \mathrm{C}$. Cool temperatures are optimal for virus replication and movement within the plant and symptom development. Water the plants every day and fertilize plants once every week.

- Virus symptoms appear as a mild mosaic of dark and light green regions on leaves and are typically detected on $2^{\text {nd }}$ trifoliate leaves and thereafter. Two to three weeks after bombardment, harvest leaves with virus symptoms, lyophilize and store at $-20^{\circ} \mathrm{C}$.

SCN-BPMV-VIGS Protocol (see Figure 1 for overview) 
- (Day 1). Seed germination (2 days). Surface-sterilize seeds with $10 \% \mathrm{v} / \mathrm{v}$ household bleach $(0.5 \%$ sodium hypochlorite) for $10 \mathrm{~min}$. Wash the seeds with running tap water for $30 \mathrm{~min}$ to remove residual bleach. Cut the required number of pieces of germination paper $\left(18^{\prime \prime} \times 7.5 "\right)$ to roll ragdolls. Fold the germination paper in half and label the fold so the label appears on the outside when rolled. Wet the germination paper with tap water. Open the folded paper (like you would a book) and arrange about 10 seeds on the right side of the paper, in a row 1 " from the top edge of the germination paper with hilum facing downward. Fold the left side over as you would close a book. Roll the germination paper from open ends tight enough to hold the seeds in place (approximate diameter will be 1 inch). The label should be seen on the outside of the ragdoll. Place the ragdolls upright in a 1-L beaker with a few milliliters of water. Cover the beaker with saran (plastic) wrap and then poke a few small holes in the wrap with a dissecting needle. Place the beaker of seeds into a $27^{\circ} \mathrm{C}$ incubator in the dark for $48 \mathrm{~h}$.

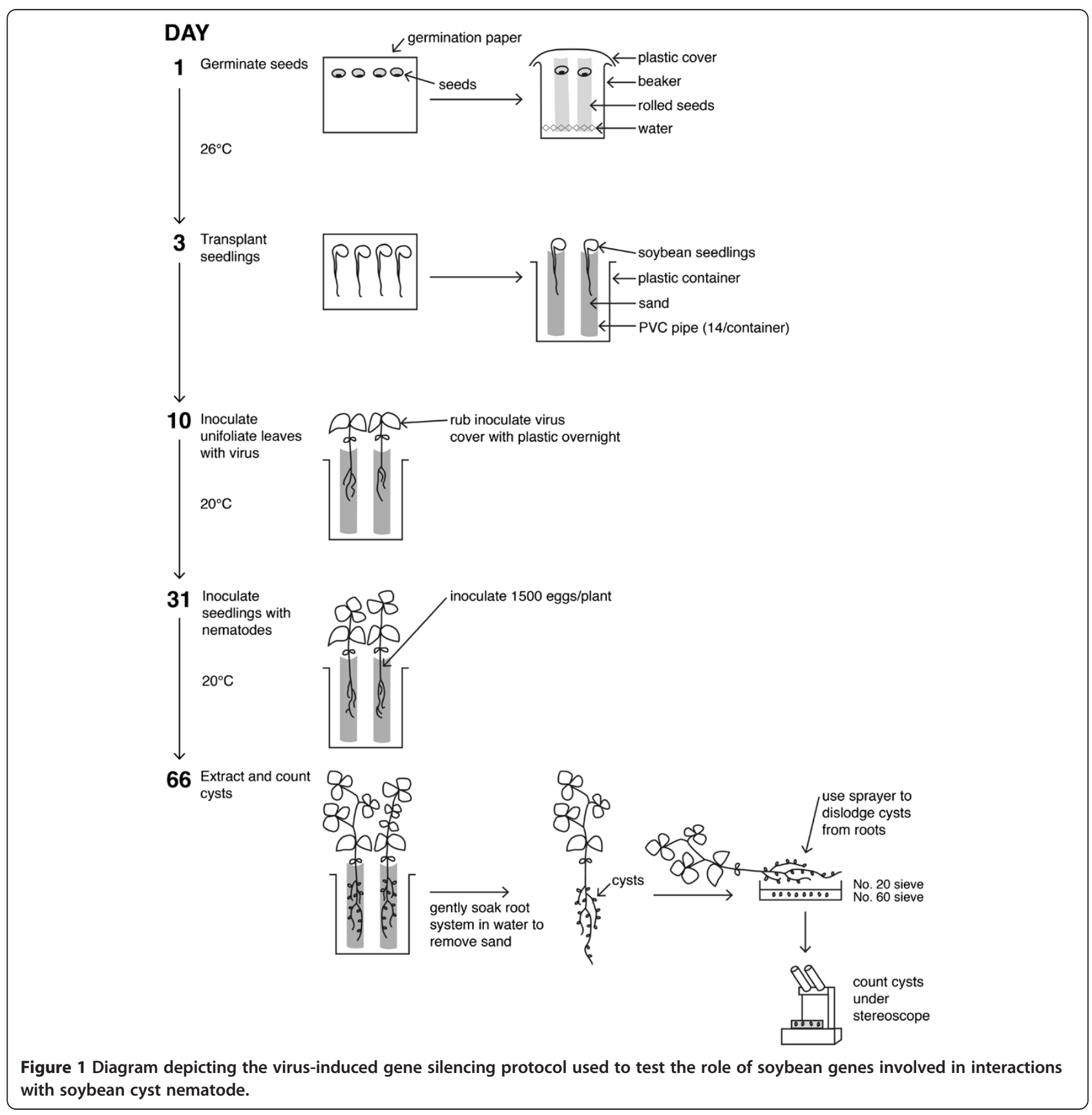


- (Day 3). After $48 \mathrm{~h}$, remove the germinated seedlings from $27^{\circ} \mathrm{C}$ incubator. Select seedlings with a healthy white radicle at least $4-6 \mathrm{~cm}$ in length and transplant into a $6 \mathrm{~cm}$ hole made in sterile river sand in $100 \mathrm{~cm}^{3}$ thin-walled polyvinyl carbonate (PVC) tubes (6" in length, 1-1/8" inside diameter) placed into a 6 qt. Bains Marie plastic container (Continental Carlisle, Oklahoma City, Oklahoma). Fourteen PVC tubes fit into a single container. One plastic container (14 plants) is used per construct to avoid virus contamination among plants infected with different VIGS constructs.

- (Day 3-10). Maintain the plants in a growth chamber set at $20^{\circ} \mathrm{C}$ with $16 \mathrm{~h}$ light, $8 \mathrm{~h}$ dark regime and $100-110 \mu \mathrm{mol} \mathrm{cm}^{-2} \mathrm{~s}^{-1}$ light intensity (7 days) (Note 4).

- (Day 10-31). Virus inoculation (21 days). To prepare inoculum, grind lyophilized BPMV-infected leaf tissue in $50 \mathrm{mM}$ potassium phosphate buffer $\mathrm{pH} 7.0$ (mix $50 \mathrm{mM} \mathrm{KH}_{2} \mathrm{PO}_{4}$ and $50 \mathrm{mM} \mathrm{K}_{2} \mathrm{HPO}_{4}$ in 3.85:6.15 ratio to achieve $\mathrm{pH} 7.0$ ). Use $25-50 \mathrm{mg}$ dry tissue/ml of the buffer (Note 5). Sprinkle carborandum on the surface of the unifoliate leaves to be inoculated. Gently wipe the leaf surface with cheesecloth 2-3 times in one direction to inflict minute wounds. Next use a fresh piece of cheesecloth wetted in inoculum $(2-3 \mathrm{ml}$ is sufficient to infect 14 plants) and gently rub across the leaf surface. Alternatively, you can rub the inoculum on the leaf surface with a gloved finger. Water plants immediately after inoculation and cover with a plastic bag to maintain humidity overnight. This will prevent the wound inoculated leaves from temporary wilting. Maintain the plants for 21 days in a growth chamber set at $20^{\circ} \mathrm{C}$ with $16 \mathrm{~h}$ light, $8 \mathrm{~h}$ dark regime and $100-110 \mu \mathrm{mol}$ $\mathrm{cm}^{-2} \mathrm{~s}^{-1}$ light intensity. Water the plants daily and fertilize weekly with Miracle-Gro (Scotts Miracle-Gro, Marysville, Ohio).

- (Day 31-66). SCN inoculation (35 days; Note 6). Extract cysts of Heterodera glycines from infested soil by flotation in water and collect on a no. 60-mesh $(250-\mu \mathrm{m})$ sieve. Crush harvested cysts gently using a drill press and collect the eggs on a no. 500-mesh $(25-\mu \mathrm{m})$ sieve [19]. Purify the eggs by centrifugal flotation on a sucrose density gradient and resuspend in water at a concentration of 750 eggs $/ \mathrm{ml}$. Using a pencil, poke two $2-2.5 \mathrm{~cm}$ deep holes in the soil close to the base of the stem on each side of the plant. Apply $1 \mathrm{ml}$ of inoculum to each hole using a $1 \mathrm{ml}$ pipette (1500 eggs/plant). Maintain the plants for 35 days in a growth chamber set at $20^{\circ} \mathrm{C}$ with $16 \mathrm{~h}$ light, $8 \mathrm{~h}$ dark regime and $100-110 \mu \mathrm{mol} \mathrm{cm} \mathrm{cm}^{-2}$ light intensity.
Water the plants daily and fertilize weekly with Miracle-Gro (Scotts Miracle-Gro, Marysville, Ohio).

- (Day 66). SCN cyst count. At 35 days post-inoculation, soak each PVC tube in a liter of water until the tube can easily slide away from the root. Gently agitate each root system in the water until the root is free of sand. Using a water sprayer, blast the root system on top of a no. 20-mesh $(750 \mu \mathrm{m})$ sieve stacked on top of a no. 60-mesh sieve to collect SCN females/cysts. Rinse cysts into $60 \mathrm{~mm}$ Petri dishes and manually count under a dissecting microscope. Analyze the treatment and controls for statistical significance using an unpaired two tailed $t$-test. Here, statistical analysis was performed using Graphpad ${ }^{\bullet}$ Prism software. Data were graphed as a vertical scatter plot and analyzed statistically using an unpaired two-tailed $t$-test.

\section{RNA analysis}

Verification of gene silencing is determined by qPCR analysis. The target gene transcript level in a root sample representative of two plants selected from each treatment is analyzed at the time of nematode inoculation (Day 31; 21 days post-virus inoculation).

- Randomly select two plants from each treatment and soak each PVC tube in a liter of water until the tube can easily slide away from the root. Wash each root system in water until the root is free of sand. For RNA extraction and analysis of silencing, harvest tissue from the middle of the root system to the tip. Combine the two root samples for each treatment, flash freeze in liquid $\mathrm{N}_{2}$, and store at $-80^{\circ} \mathrm{C}$.

- Extract total RNA from $100 \mathrm{mg}$ of root tissue using the RNeasy Plant Mini Kit (Qiagen, Valencia, CA) and remove contaminating DNA by on-column DNase I digestion.

- Total RNA can be quantified using a nanodrop ND-1000 (ThermoScientific,Wilmington, DE) and quality assessed by analysis on a $2 \%$ agarose gel.

- Synthesize cDNA using the Superscript III cDNA Synthesis Kit (Invitrogen, Grand Island, NY) according to the manufacturer's instructions.

- Perform qPCR analysis. We used the Applied Biosystems 7500 Real-Time PCR System.

Gene-specific primers were designed using the Primer Express software (Applied Biosystems, Carlsbad, CA). Cycling parameters were as follows: $50^{\circ} \mathrm{C}$ for $2 \mathrm{~min}, 95^{\circ} \mathrm{C}$ for $10 \mathrm{~min}$, and 40 cycles of $95^{\circ} \mathrm{C}$ for $15 \mathrm{~s}$ and $60^{\circ} \mathrm{C}$ for $1 \mathrm{~min}$. A soybean ubiquitin gene [Genbank:D28123] was used as an endogenous control gene for normalization of samples. 
Note 1: VIGS vector requests should be made to John Hill (johnhill@iastate.edu) or Steve Whitham (swhitham@iastate.edu), Iowa State University, Ames, IA.

Note 2: Soybean cultivars differ in susceptibility to BPMV infection. Soybean cultivar Williams 82 is highly susceptible. The recombinant inbred lines (EXF63, EXF67) used in our study were less susceptible to BPMV than Williams 82. Thus, the silencing efficiency attained can vary between cultivars.

Note 3: Preparation of gold particles: Weigh $30 \mathrm{mg}$ gold particles (BioRad cat. No. 165-2263), resuspend in 100\% ethanol in a $1.5 \mathrm{ml}$ tube, vortex well and let it sit for $10 \mathrm{~min}$ at room temperature. Centrifuge the suspension and discard the supernatant. Add $1 \mathrm{ml}$ sterile water, vortex well and centrifuge again to pellet the gold particles. Repeat this washing 2 more times. Add $0.5 \mathrm{ml}$ sterile $50 \% \mathrm{v} / \mathrm{v}$ glycerol to the final pellet of gold particles and vortex well to re-suspend. Finally, while vortexing at low speed, aliquot $50 \mu \mathrm{l}$ into several $0.5 \mathrm{ml}$ tubes and store at $-20^{\circ} \mathrm{C}$. Each aliquot is enough to coat DNA that can be used for three separate bombardments.

Note 4: Alternatively, seeds can be germinated, and seedlings grown at $26^{\circ} \mathrm{C}$, up until the day of virus inoculation. This will reduce the time to the two-leaf stage by 1-2 days.

Note 5: The amount of tissue required depends on the virus titer of the infected leaf tissues used for inoculum preparation. In our experience, a ratio of 1:20 w/v of tissue results in reliable virus infection on plants. Fresh tissues can also be used, however, more tissue per $\mathrm{ml}$ of buffer $(1: 10 \mathrm{w} / \mathrm{v})$ is recommended.

Note 6: We have carried out experiments to determine the time point at which optimum virus levels are achieved in the roots. In a time-course RT-PCR analysis of root tissues harvested at different days post-virus (dpv) inoculation of leaves, we detected BPMV in roots by $6 \mathrm{dpv}$ (Figure 2; $\mathrm{V}_{6}$ ). BPMV carrying a portion of a soybean Actin gene (BPMV-Actin) was detected in roots at 12 $\mathrm{dpv}$ (Figure 2; $\mathrm{A}_{12}$ ). We also examined the timing of GFP gene silencing in composite plants [20] expressing GFP in hairy roots. By $14 \mathrm{dpv}$ inoculation we could detect silencing of GFP in roots and the silencing increased by day 19 (Figure 3). Based on these data, we selected $21 \mathrm{dpv}$ inoculation as the optimum timepoint for SCN inoculation. This time scale has also been demonstrated in roots of stable transgenic soybean plants expressing GFP [21].

\section{Findings}

Here we present the detailed description of a SCNBPMV-VIGS pipeline to demonstrate the usefulness of VIGS methodology in studying genes involved in soybean-nematode interactions. A 328 bp fragment corresponding to a SHMT gene mapped to the Rhg4 locus, a

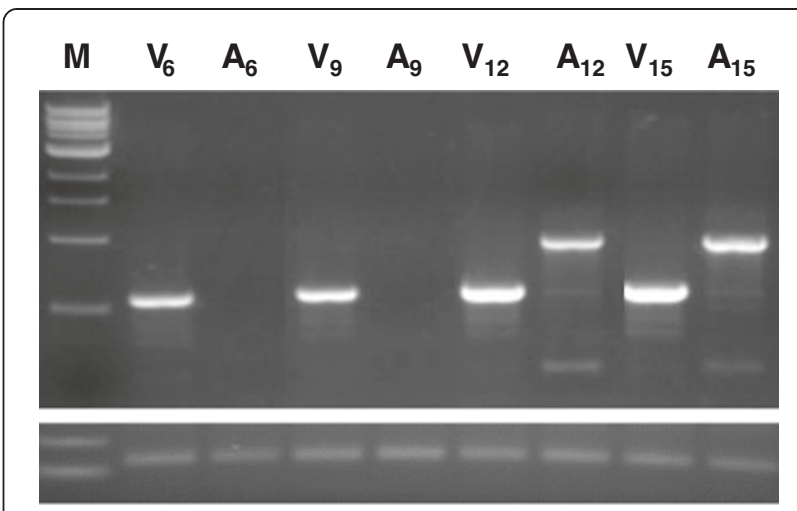

Figure 2 RT-PCR analysis to detect BPMV in the roots of soybean plants. RNA was prepared from roots of plants at different days post virus (dpv) inoculation of leaves and used for RT-PCR analysis with BPMV-specific primers. Lanes: M, 1 kb ladder (NEB); $V$, BPMV only; A, BPMV-Actin. Subscripts denote the dpv. Bottom panel, soybean ubiquitin gene [Genbank:D28123] internal control.

major quantitative trait locus for SCN resistance [22], was used for our VIGS experiments. Plants were analyzed at $21 \mathrm{dpv}$ inoculation for RNA silencing. qPCR analysis demonstrated an average of $70 \%$ reduction of RNA levels (Figure 4). VIGS plants were infected with $\mathrm{SCN}$ at $21 \mathrm{dpv}$ inoculation and the cysts were counted 35 days after SCN inoculation. SHMT-VIGS silenced plants showed a statistically significant increase in susceptibility to SCN compared to control plants inoculated with BPMV empty vector in repeated experiments (Figure 4). These experiments demonstrate the successful silencing of a gene involved in SCN resistance. The RNA silencing varied from $65-74 \%$ and is as expected for VIGS silencing. The SHMT gene has been shown to be required for SCN resistance by TILLING, RNAi, and complementation analysis [23].

\section{Conclusions}

Although VIGS is routinely used for functional studies of genes involved in aboveground interactions, the use of VIGS to study belowground interactions is limited. The development of an efficient VIGS protocol is challenging, in particular when you are dealing with root-biotic interactions. This is due to the fact that inoculation of the virus needs to be carefully timed with inoculation of the infecting organism so that optimal target gene silencing is achieved at the time of infection. In addition, the temperature optimums for the virus and infecting organism must be considered. While our methodology combined established SCN phenotyping and soybean VIGS methods, several specific modifications were made to overcome these challenges. We first analyzed for the presence of BPMV in roots and then monitored silencing of GFP in transgenic hairy roots and the roots of stable transgenics [21] utilizing a GFP-VIGS construct. This 

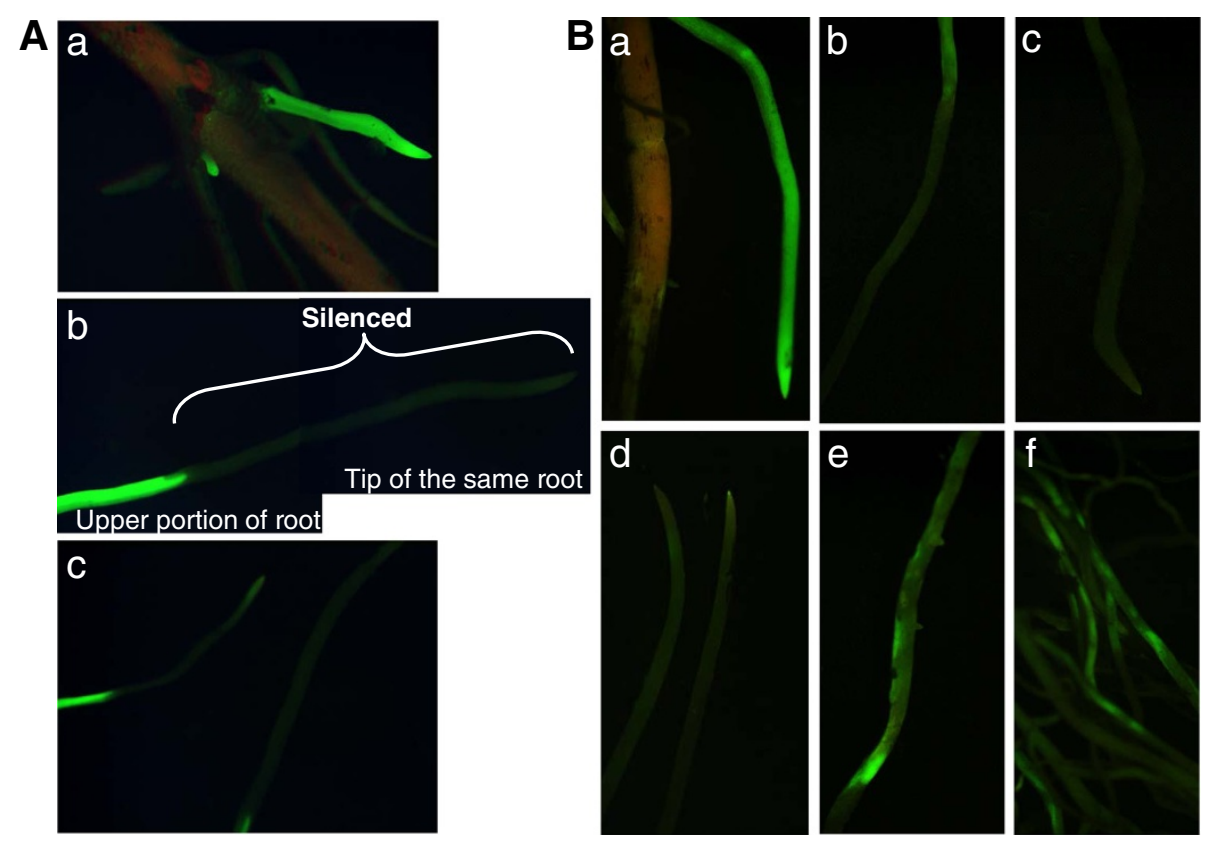

Figure 3 GFP silencing in transgenic hairy roots expressing GFP using BPMV-GFP-VIGS. GFP silencing was monitored 10 to 25 days post virus (dpv) inoculation. A. GFP-VIGS at $14 \mathrm{dpv}$. (a) control roots showing GFP expression under control of a soybean ubiquitin promoter [24], (b) and (c) silenced roots. B. GFP-VIGS at 19 dpv. (a) control hairy roots, (b)-(d) root tips showing VIGS silencing, (e)-(f) more mature roots showing unevenly distributed silencing.

allowed us optimize the timing of SCN inoculation of roots (21 dpv) relative BPMV inoculation of foliar tissues. Normally SCN bioassays are performed at $27^{\circ} \mathrm{C}$. Since a lower temperature $\left(20^{\circ} \mathrm{C}\right)$ is optimal for BPMV, we conducted SCN bioassays at this lower temperature.
To compensate for developmental delays of SCN, we extended the SCN bioassay by five days (from 30 to 35 days). VIGS is a valuable tool for functional genomic studies in crop plants like soybean, where whole plant transformation is difficult and time consuming. This has been

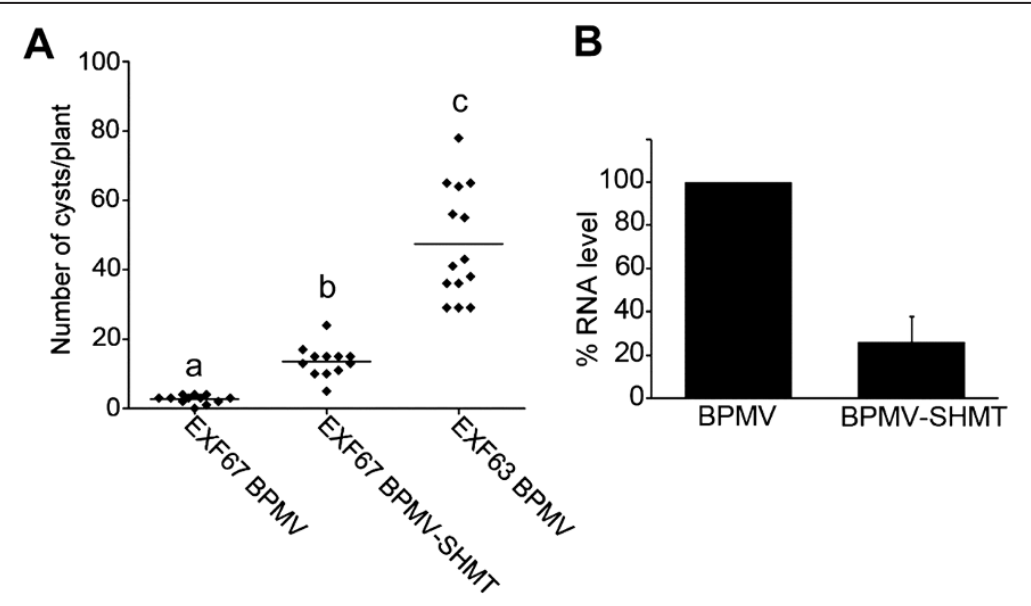

Figure 4 Soybean cyst nematode development in soybean roots silenced for SHMT using virus-induced gene silencing. EXF67 and EXF63 are SCN-resistant and SCN-susceptible RILS, respectively. Ten days after planting, soybean leaves were rub-inoculated with either BPMV (Bean pod mottle virus) or BPMV containing a fragment of the SHMT gene sequence (BPMV-SHMT). Diamonds represent the number of cysts on a single root system at 35 days post-inoculation. At least twelve plants per genotype treatment were used. Cysts were collected on a $250 \mu \mathrm{M}$ sieve and counted manually under a dissecting microscope. Six independent experiments were performed showing similar results. Data from one experiment are presented. Different letters denote a significant difference at $P<0.0001$. (B) Effect of BPMV-SHMT on SHMT transcript levels in soybean roots of ExF67. Reprinted from reference [23] with permission from Nature. 
validated by recent discoveries of genes involved in Asian soybean rust-soybean interactions [16,17]. Our methodology for VIGS in soybean roots described here can be adapted for genes involved in host responses to other root pathogens, symbiosis, mineral nutrition, abiotic stress responses, root development, among other functions. The enhancements recently made to existing VIGS vectors [15] could potentially improve the silencing further. Additionally, different methods of inoculation can be tested for increased efficiency of silencing and faster screening of candidate genes. One limitation of VIGS is that a negative result cannot rule out a role for a particular gene in a certain function because gene silencing is never $100 \%$. In such cases, VIGS experiments must be combined with other reverse genetic approaches such as RNAi or mutagenesis.

\section{Competing interests}

The authors declare that they have no competing interests.

\section{Authors' contributions}

PKK, PSJ, TJB, and MGM conceived and designed the study. PKK and RH developed the SCN-BPMV-VIGS pipeline. GY performed the qRT-PCR analysis to detect BPMV in roots, PKK and NWG performed the composite plant assays to monitor GFP silencing in roots, PKK and RH carried out the SHMT-VIGS analysis. JH and SAW provided materials and intellectual input for VIGS analysis. PKK and MGM wrote the manuscript. All authors critically revised and approved the final manuscript.

\section{Acknowledgements}

The authors thank Ginny Booker for graphic art assistance with Figure 1. This work was supported by the National Science Foundation Plant Genome Research Program (grant no. 0820642 to S.W., J.H., M.G.M. and T.J.B.), the Missouri Soybean Merchandising Council (project no. 258 to M.G.M.), the North Central Soybean Research Program and lowa Soybean Association.

\section{Author details}

${ }^{1}$ Division of Plant Sciences, Christopher S. Bond Life Sciences Center and Interdisciplinary Plant Group, University of Missouri, Columbia, MO 65211, USA. ²Department of Plant Pathology and Microbiology, lowa State University, Ames, IA 50011, USA. ${ }^{3}$ Current address: Pioneer Hi-Bred, Johnston IA, 50131, USA. ${ }^{4}$ Current address: Beadle Center for Biotechnology, University of Nebraska, Lincoln NE, 68588, USA.

Received: 19 December 2012 Accepted: 3 July 2013

Published: 6 July 2013

\section{References}

1. Lu R, Martin-Hernandez AM, Peart JR, Malcuit I, Baulcombe DC: Virus-induced gene silencing in plants. Methods 2003, 30:296-303.

2. Donaire L, Barajas D, Martinez-Garcia B, Martinez-Priego L, Pagan I, Llave C: Structural and genetic requirements for the biogenesis of tobacco rattle virus-derived small interfering RNAs. J Virol 2008, 82:5167-5177.

3. Burch-Smith TM, Anderson JC, Martin GB, Dinesh-Kumar SP: Applications and advantages of virus-induced gene silencing for gene function studies in plants. Plant J 2004, 39:734-746.

4. Robertson D: VIGS vectors for gene silencing: many targets, many tools. Annu Rev Plant Biol 2004, 55:495-519.

5. Burton RA, Gibeaut DM, Bacic A, Findlay K, Roberts K, Hamilton A, Baulcombe DC, Fincher GB: Virus-induced silencing of a plant cellulose synthase gene. Plant Cell 2000, 12:691-706.

6. Romeis T, Ludwig AA, Martin R, Jones JD: Calcium-dependent protein kinases play an essential role in a plant defence response. EMBO J 2001, 20:5556-5567.

7. Liu Y, Schiff M, Dinesh-Kumar SP: Virus-induced gene silencing in tomato. Plant J 2002, 31:777-786
8. Jin H, Axtell MJ, Dahlbeck D, Ekwenna O, Zhang S, Staskawicz B, Baker B: NPK1, an MEKK1-like mitogen-activated protein kinase kinase kinase, regulates innate immunity and development in plants. Dev Cell 2002, 3:291-297.

9. Peart JR, Lu R, Sadanandom A, Malcuit I, Moffett P, Brice DC, Schauser L, Jaggard DA, Xiao S, Coleman MJ, et al: Ubiquitin ligase-associated protein SGT1 is required for host and nonhost disease resistance in plants. Proc Natl Acad Sci USA 2002, 99:10865-10869.

10. Kandoth PK, Ranf S, Pancholi SS, Jayanty S, Walla MD, Miller W, Howe GA, Lincoln DE, Stratmann JW: Tomato MAPKs LeMPK1, LeMPK2, and LeMPK3 function in the systemin-mediated defense response against herbivorous insects. Proc Natl Acad Sci USA 2007, 104:12205-12210.

11. Fu DQ, Zhu BZ, Zhu HL, Jiang WB, Luo YB: Virus-induced gene silencing in tomato fruit. Plant J 2005, 43:299-308.

12. Virus-induced gene silencing. In, Methods in Molecular Biology Edited by Annette B. New York: Humana Press; 2013:975.

13. Unver T, Budak H: Virus-induced gene silencing, a post transcriptional gene silencing method. Int J Plant Genomics 2009, 2009:198680.

14. Zhang C, Yang C, Whitham SA, Hill JH: Development and use of an efficient DNA-based viral gene silencing vector for soybean. Mol Plant Microbe Interact 2009, 22:123-131.

15. Zhang C, Bradshaw JD, Whitham SA, Hill JH: The development of an efficient multipurpose bean pod mottle virus viral vector set for foreign gene expression and RNA silencing. Plant Physiol 2010, 153:52-65.

16. Meyer JD, Silva DC, Yang C, Pedley KF, Zhang C, van de Mortel M, Hill JH, Shoemaker RC, Abdelnoor RV, Whitham SA, Graham MA: Identification and analyses of candidate genes for rpp4-mediated resistance to Asian soybean rust in soybean. Plant Physiol 2009, 150:295-307.

17. Pandey AK, Yang C, Zhang C, Graham MA, Horstman HD, Lee Y, Zabotina OA, Hill JH, Pedley KF, Whitham SA: Functional analysis of the Asian soybean rust resistance pathway mediated by Rpp2. Mol Plant Microbe Interact 2011, 24:194-206.

18. Schmutz J, Cannon SB, Schlueter J, Ma J, Mitros T, Nelson W, Hyten DL, Song Q, Thelen JJ, Cheng J, et al: Genome sequence of the palaeopolyploid soybean. Nature 2010, 463:178-183.

19. Faghihi J, Ferris JM: An efficient new device to release eggs from Heterodera glycines. J Nematol 2000, 32:411-413.

20. Kereszt A, Li D, Indrasumunar A, Nguyen CD, Nontachaiyapoom S, Kinkema M Gresshoff PM: Agrobacterium rhizogenes-mediated transformation of soybean to study root biology. Nat Protoc 2007, 2:948-952.

21. Juvale PS, Hewezi T, Zhang C, Kandoth PK, Mitchum MG, Hill JH, Whitham SA, Baum TJ: Temporal and spatial Bean pod mottle virus-induced gene silencing in soybean. Mol Plant Pathol 2012, 13:1140-1148.

22. Meksem K, Pantazopoulos P, Njiti VN, Hyten LD, Arelli PR, Lightfoot DA 'Forrest' resistance to the soybean cyst nematode is bigenic: saturation mapping of the Rhg1 and Rhg4 loci. Theor Appl Genet 2001, 103:710-717.

23. Liu S, Kandoth PK, Warren SD, Yeckel G, Heinz R, Alden J, Yang C, Jamai A, El-Mellouki T, Juvale PS, et al: A soybean cyst nematode resistance gene points to a new mechanism of resistance to pathogens. Nature 2012, 492:256-260.

24. Hernandez-Garcia CM, Bouchard RA, Rushton PJ, Jones ML, Chen X, Timko MP, Finer JJ: High level transgenic expression of soybean (Glycine max) GmERF and Gmubi gene promoters isolated by a novel promoter analysis pipeline. BMC Plant Biol 2010, 10:237.

doi:10.1186/1756-0500-6-255

Cite this article as: Kandoth et al:: A virus-induced gene silencing method to study soybean cyst nematode parasitism in Glycine max. BMC Research Notes 2013 6:255. 